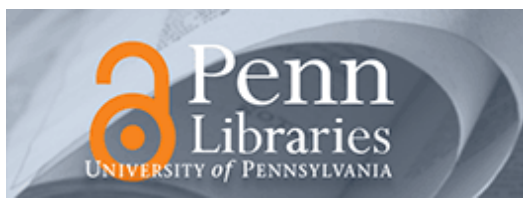

University of Pennsylvania ScholarlyCommons

Wharton Pension Research Council Working Papers

Wharton Pension Research Council

$9-1-2013$

\title{
Technical Review Panel for the PIMS Model: Final Report
}

Olivia S. Mitchell

The Wharton School, University of Pennsylvania, mitchelo@wharton.upenn.edu

Follow this and additional works at: https://repository.upenn.edu/prc_papers

Part of the Economics Commons

Mitchell, Olivia S., "Technical Review Panel for the PIMS Model: Final Report" (2013). Wharton Pension Research Council Working Papers. 113.

https://repository.upenn.edu/prc_papers/113

This paper is posted at ScholarlyCommons. https://repository.upenn.edu/prc_papers/113

For more information, please contact repository@pobox.upenn.edu. 


\title{
Technical Review Panel for the PIMS Model: Final Report
}

\begin{abstract}
In April of 2013, the Pension Research Council of the Wharton School at the University of Pennsylvania convened a Technical Review Panel, comprising ten experts whose task it was to review the Pension Benefit Guaranty Corporation's (PBGC) Pension Insurance Modeling System (PIMS), including inputs, outputs, and model assumptions. The review was intended to provide a formal evaluation of the technical adequacy of the model by outside experts. Each expert participating on the Technical Panel was asked to review background material (see References) and focus on a particular aspect of the PIMS model. The list of panelists and topics was developed by the Council in discussion with the Social Security Administration (SSA). This report and the appended papers herein from our Technical Panel comprise the Final Report under this project. The Panel's key findings may be summarized as follows: 1 . The PIMS models are an important and valuable tool in modeling the Agency's liability risk. To the best of our knowledge, there is no other model that can do a comparable job. 2. Nevertheless, some improvements could be integrated in the Agency's approach to modeling. Those deserving highest priority attention in the experts' view are the following: a) Incorporating systematic mortality risk (i.e., treat mortality and longevity as stochastic variables); b) Including new asset classes increasingly found in defined benefit plan portfolios (e.g. commercial real estate, private equity funds, infrastructure, hedge funds, and others); c) Developing a more complex model for the term structure of interest rates; and d) Incorporating an option value approach to pricing the insurance provided. 3 . The Agency could also do more to communicate the range of uncertainty and potential for problems associated with the PBGC's financial status. This could include additional information including the Conditional Value at Risk ( $\mathrm{CVaR}$ ), and perhaps an 'intermediate,' 'optimistic', and 'pessimistic' set of projected outcomes, as well as the expected 'date of exhaustion' for assets backing pension benefits insured by the PBGC.
\end{abstract}

\section{Disciplines}

Economics 


\title{
Technical Review Panel for the PIMS Model: Final Report
}

\author{
Olivia S. Mitchell
}

September 2013

\author{
PRC WP2013-07 \\ Pension Research Council Working Paper \\ Pension Research Council \\ The Wharton School, University of Pennsylvania \\ 3620 Locust Walk, 3000 SH-DH \\ Philadelphia, PA 19104-6302
}

Tel.: 215.898.7620 Fax: 215.573.3418

Email: prc@wharton.upenn.edu

http://www.pensionresearchcouncil.org

The research reported herein was pursuant to a grant from the U.S. Social Security Administration (SSA) funded as part of the Retirement Research Consortium (RRC); the author also acknowledges support from The Pension Research Council at The Wharton School. All findings and conclusions expressed are solely those of the author and do not represent the views of the SSA or any agency of the federal government, the MRRC, the PRC, or The Wharton School at the University of Pennsylvania. All findings, interpretations, and conclusions of this paper represent the views of the authors and not those of the Wharton School or the Pension Research Council. (C)2013 Pension Research Council of the Wharton School of the University of Pennsylvania. All rights reserved. 


\title{
Technical Review Panel for the PIMS Model: Final Report
}

\begin{abstract}
$\underline{\text { Abstract }}$
In April of 2013, the Pension Research Council of the Wharton School at the University of Pennsylvania convened a Technical Review Panel, comprising ten experts whose task it was to review the Pension Benefit Guaranty Corporation's (PBGC) Pension Insurance Modeling System (PIMS), including inputs, outputs, and model assumptions. The review was intended to provide a formal evaluation of the technical adequacy of the model by outside experts. Each expert participating on the Technical Panel was asked to review background material (see References) and focus on a particular aspect of the PIMS model. The list of panelists and topics was developed by the Council in discussion with the Social Security Administration (SSA). This report and the appended papers herein from our Technical Panel comprise the Final Report under this project.
\end{abstract}

The Panel's key findings may be summarized as follows:

1. The PIMS models are an important and valuable tool in modeling the Agency's liability risk. To the best of our knowledge, there is no other model that can do a comparable job.

2. Nevertheless, some improvements could be integrated in the Agency's approach to modeling. Those deserving highest priority attention in the experts' view are the following:

a) Incorporating systematic mortality risk (i.e., treat mortality and longevity as stochastic variables);

b) Including new asset classes increasingly found in defined benefit plan portfolios (e.g. commercial real estate, private equity funds, infrastructure, hedge funds, and others);

c) Developing a more complex model for the term structure of interest rates; and

d) Incorporating an option value approach to pricing the insurance provided.

3. The Agency could also do more to communicate the range of uncertainty and potential for problems associated with the PBGC's financial status. This could include additional information including the Conditional Value at Risk (CVaR), and perhaps an 'intermediate,' 'optimistic', and 'pessimistic' set of projected outcomes, as well as the expected 'date of exhaustion’ for assets backing pension benefits insured by the PBGC.

\section{Olivia S. Mitchell}

Executive Director of the Pension Research Council

The Wharton School, University of Pennsylvania

3620 Locust Walk, 3005 SH-DH

Philadelphia, PA 19104-6302 


\section{Technical Review Panel for the PIMS Model: \\ Final Report}

Olivia S. Mitchell

\section{Introduction}

The Pension Benefit Guaranty Corporation (PBGC) is a federal corporation founded under the Employee Retirement Income Security Act (ERISA) of 1974. Its goal is to protect benefits promised by the private sector defined benefit (DB) pension plans in the United States via two insurance programs covering, respectively, single employer and multiemployer plans. To carry out its work, the Agency has developed two simulation models over the past two decades, the Single Employer Pension Insurance Modeling System (SE-PIMS), and the Multiemployer Pension Insurance Modeling System (ME-PIMS). These use several input parameters regarding actuarial assumptions, capital market developments, the evolution of assets and liabilities, and plan terminations, to model how the Agency’s financial status might unfold over the next decade or two. These models require running many simulations to derive a range of possible estimates of the PBGC’s future financial status.

The meeting in April 2013 of the Technical Panel followed up on an earlier Technical Panel review in 1996 hosted by the Pension Research Council at the Wharton School. The prior discussion offered expert commentary on an early version of the SE-PIMS model then just under development. For the 2013 Panel, we invited ten experts to provide their views and judgment regarding the soundness and applicability of the current version of the PIMS models, regarding economic, finance, statistical, and actuarial principles and reasonableness of key assumptions and program inputs. These experts also were asked to offer their assessments on how actuarial and statistical calculations are undertaken in the models, model calibrations, and presentation of 
output. The goal of this meeting, as in 1996, was to offer suggestions on how the PIMS systems could be made more useful for analysis and policy.

\section{Background}

The Pension Benefit Guaranty Corporation (PBGC) is, according to the 2012 Annual Report, a "federal corporation...[that] guarantees payment of basic pension benefits earned by nearly 43 million of America's workers and retirees participating in nearly 26,000 private-sector defined benefit pension plans. The Corporation receives no funds from general tax revenues. Operations are financed by insurance premiums paid by companies that sponsor defined benefit pension plans or from the plans’ assets, investment income, and assets from terminated plans.” Its governance structure includes a Director appointed by the President and confirmed by the Senate; the Agency is overseen by a Board of Directors chaired by the Secretary of Labor and includes the Secretaries of Commerce and Treasury (ex officio).

The PBGC has two components to its pension insurance program. One covers defined benefit pensions offered by employers in the private sector under the Single Employer Plan program (SE) involving almost 33 million active and retired workers in about 24,000 pension plans. The other covers so-called Taft-Hartley plans under the Multiemployer program (ME) which includes about 10 million active and retired employees in some 1,500 pension plans. In 2013, single employer plans paid to the PBGC in insurance premiums a flat amount of $\$ 42$ perworker or retiree and also a variable amount of $\$ 9$ per $\$ 1000$ of unfunded vested benefits. ${ }^{1}$ Multiemployer plans paid a flat premium of $\$ 12$ per worker or retiree. Retiree benefits are guaranteed by the PBGC up to a cap: in 2013, covered employees claiming benefits at age

\footnotetext{
1 All 2013 data are taken from http://www.pbgc.gov/res/factsheets/page/pbgcfacts.html
} 
65 could receive a maximum of $\$ 4,789.77 /$ month $(\$ 57,477.24 /$ year) for the single employer plan, payable as a single life annuity. In the multi-employer arena, the annual benefit guaranteed can be up to $\$ 12,870 .^{2}$ In the multi-employer arena, the annual guaranteed benefit is up to $\$ 12,870$. The guaranteed amount is reduced actuarially for earlier claimants (or for those having survivor benefits). The guarantee is increased for those who claim post-age 65 .

For a variety of reasons, the PBGC's finances are not in long-term balance. ${ }^{3}$ The Agency’s 2012 Annual Report noted that the SE program had liabilities of \$112.1 billion and assets of $\$ 83.0$ billion, for a deficit of $\$ 29.1$ billion. For the ME program, the Agency reported liabilities of $\$ 7$ billion and assets of $\$ 1.8$ billion, producing a deficit of $\$ 5.2$ billion. The Agency also projects future income and payout streams for 10 or 20 years into the future, though it acknowledges substantial uncertainty regarding these projections. Estimates of the SE program's financial position in FY 2022 range from a $\$ 66$ billion deficit at the $15^{\text {th }}$ percentile to a $\$ 1$ billion surplus at the $85^{\text {th }}$ percentile, with a mean estimate of a $\$ 32$ billion deficit, all values expressed in present value terms. Estimates of the ME program's financial position in FY2022 range from a $\$ 43$ billion deficit at the $15^{\text {th }}$ percentile to a $\$ 9$ billion deficit at the $85^{\text {th }}$ percentile, with a mean estimate of a \$26 billion deficit, all values expressed in present value terms. These "long-term" estimates include "probable terminations" from plans that it is likely to have to take over in the future, but the Agency does not book as losses those plans it deems to be "reasonably possible terminations"; both "probable terminations" and "reasonably possible terminations" are determined in accordance with the FASB Accounting Standards Codification Section 450, Contingencies.

${ }^{2}$ Multiemployer information is available at http://www.pbgc.gov/res/factsheets/page/pbgcfacts.html.

${ }^{3}$ All data in this paragraph are taken from the PBGC 2012 Exposure Report 


\section{Key Findings from the Technical Panel Review}

The Technical Panel offered several comments and suggestions regarding the way the PIMS models assets, liabilities, and the interactions between the two. Moreover the Panel provided suggestions on how the PBGC might enhance the way it reports its status to policymakers and the public, so as to better communicate the risks and opportunities the Agency faces. We briefly discuss each in turn, and we refer interested readers to the individual expert papers produced under the Panel’s auspices, for further detail (see References).

\section{Modeling Defined Benefit Pension and PBGC Liabilities}

PBGC liabilities consist of the vested accrued benefits payable under Title IV of ERISA (i.e., guaranteed and, in some circumstances, non-guaranteed benefits provided under the law) of already-terminated pension plans, as well as the Title IV benefits of insured underfunded plans that are likely to terminate in the future. Several of the experts on the Technical Panel had comments and suggestions regarding how the PIMS models treat such liabilities.

The cash flows owed by the PBGC consist of pension benefits promised to active, terminated vested, and retired workers under each plan’s benefit rules. In terminated SE plans, these are relatively straightforward to model as they are fixed as of the date of the plan's termination. As Novy-Marx (2013) and others note, at plan termination, the PBGC takes over the plan's accrued benefit obligation (ABO), with benefits computed given known formulas and frozen wage, tenure, and age distributions as of the termination date.

Nonetheless, even here, important unknowns remain, such as when participants will retire and how long participants (and their survivors) will live in the future. Thus demographers and economists have modeled systematic mortality shocks that could pose substantial risk to PBGC solvency in the future. Maurer (2013) notes that this form of uncertainty can now be modeled 
and, accordingly, may be integrated into the PIMs model to determine the future path of the Agency's payouts. The Agency could also cost out how expensive it would be to hedge stochastic mortality risk. And the PIMS model currently includes only single male mortality tables; these could be extended allowing for both female and survivor tables. ${ }^{4}$

Greater uncertainty pertains to the possible time path of benefits associated with future terminations, inherently a more complex process and one which, in the experts' views, may understate the size of the problem faced. One reason is that PIMS assumes that plans will only be terminated in distress, and hence it assumes no voluntary (i.e., standard) termination of fully funded pensions. But as several of the experts note, this is increasingly not the case. Fuerst and Bone point out that many single employer DB plans have recently de-risked by outsourcing their pensions to insurers. This reduces the future premiums payable to the PBGC, and it also diminishes the asset pool available to the Agency in the event of future terminations. ${ }^{5}$ Segal notes that allowing for newer plans of the hybrid and cash balance variety could also imply the need for different ways to model future liabilities.

In the case of ME plans, benefit payouts can be reduced under certain circumstances; it is unclear whether this flexibility in benefit payments will be extended to SE plans in the future. Yet as Bone points out, the ME program appears to be in a worse condition than the SE program, as ME plans come to the Agency for financial assistance when they have no assets to pay the promised benefits. For this and other reason (e.g., the extremely low premium), costs associated with the ME plans may pose more risk to the PBGC than does SE plan underfunding.

\footnotetext{
4 The Agency has noted in comments to the Panel's report that, although there is no direct adjustment for female mortality, the initial PIMS liabilities are recalibrated to each plans' reported liabilities which indirectly adjusts them to reflect the plan's female mortality.

5 The Agency has noted in comments to the Panel's report that concern about the diminution of the asset pool in the event of future terminations is unwarranted in the context of standard terminations, since these are fully funded.
} 
Much of the Panel discussion focused on how to bring an options-based approach into PIMS models. The goal of doing so would be to link the factors that drive plan sponsor terminations and plan underfunding to stock market risk. ${ }^{6}$ The options approach differs from a Net Present Value (NPV) method, by taking into account the possibility that company management will react to market changes dynamically and strategically. That is, this approach models alternative scenarios to identify the best corporate action given different outcomes. Since companies are modeled as reacting sensibly to uncertain financial outcomes, the plan sponsors can take advantage of uncertainty to reduce volatility in profitability compared to a conventional NPV metric. The risk-neutral valuation methodology takes into account the probability distribution of risk and typically discounts outcomes using a risk-free rate.

Lucas notes that such an approach could be usefully built on top of the plan-specific computations that the PIMS models already incorporate. The Congressional Budget Office in 2005 developed a somewhat simplified method of modeling the PBGC's problem which demonstrated proof of concept. This work focused on the joint probabilities of sponsor bankruptcy and DB plan underfunding, and it generated much larger estimates of funding shortfalls; these resulted from projected smaller asset recoveries, less premium income, and higher liabilities than the actuarial approach. ${ }^{7}$ That effort suggested that taking into account risk in this way would roughly double premium costs. One important reason for this is that the distribution of liabilities is likely to be characterized by so-called "fat tails," referring to the potential for large losses in the worst-case scenarios, as Segal, Bone, and Novy-Marx point out.

\footnotetext{
${ }^{6}$ The Agency has noted that, in the current PIMS model, both plan sponsors' bankruptcy risks and plan funding are linked to stock market risk and both links can be shown to have significant effects in PIMS projections. Nevertheless, the Agency has not published extended model output demonstrating the sensitivities of those links.

${ }^{7}$ PBGC has done similar analysis using the current model framework but this has been used internally and is not publicly available.
} 
A related theme that the Panel debated was how to summarize the system's liabilities at any point in time and over future time periods. Current practice is to report expected present discounted values (PVs) using Treasury rates to do the discounting. But as Lucas notes, this approach has a fundamental but potentially fixable shortcoming: it cannot be used to answer questions about market valuation of future streams of cash flows. Moreover, as Novy-Marx points out, which liability concept to use depends on the observer's vantage point. From the perspective of the covered insured active and retired pension plan participants, the guarantee embodies some risk: the system's assets are insufficient to meet all future benefits that might be paid, and the PBGC's guarantee is not backed by the full faith and credit of the Federal government. Absent a large transfer from Congress to cover its future cash flows, it is unlikely that all benefits can be paid in the long run. ${ }^{8}$ From an insurer's perspective, the right way to measure possible liabilities is to measure the risk-neutral valuation of the insurance. An approach favored by some would be to have the PBGC provide the distribution of projected future cash flow paths it guarantees

\section{Modeling Assets}

Next we summarize the Panel's key suggestions regarding how the PBGC models assets in the PIMS. Geczy notes that the current approach estimates risk and return patterns drawing on historical data, assuming a fixed real interest rate and holding constant historical correlations. But having experienced the recent global financial crisis, we now know that tail risk is far more of a concern than previously anticipated. Accordingly, most of the experts felt that the PIMS model would benefit from stress testing in terms of its sensitivity to extreme events and time-

\footnotetext{
${ }^{8}$ The PBGC's projections suggest that the SE program will be able to cover promised benefits for the next decade given its assumptions, whereas the ME program is likely to run short.
} 
varying returns, relaxing the 'random walk' approach to modeling risk.

A related point emphasized by Maurer was that the PIMS model currently relies heavily on a relatively simple model for a single interest rate - the 30 year Treasury rate. This is important since the interest rate model is used as an input for actuarial valuation of liabilities of terminated and ongoing plans; to determine minimum contribution rates; to specify the return on PBGC assets for terminated plans; to set the yield for corporate bonds; to set the inflation rate; to set the nominal benefit growth (since inflation is related to the nominal interest rate); and to calculate the present value of PBGC claims. Yet modern tools now exist for more complete and comprehensive models of the complete term structure of interest rates, and several experts felt this could be a fertile area for model development.

Additionally, several Panel members highlighted the fact that the DB plan asset mix is currently assumed in the PIMS model to be a 60/40 US stock/bond split. But as Geczy, Maurer, and Fabozzi emphasize, today's pension plans hold more alternatives and are more internationally diversified. These alternative assets are quite varied, and they include commercial real estate, private equity funds, infrastructure investments, hedge funds, and other holdings. Evidently, including additional relatively illiquid assets in the PIMS model would be complex. As Fabozzi notes, there is a tradeoff between the speed at which the model can be run, versus more complex assumptions about the assets held and the pattern of capital market returns.

\section{Considerations Regarding the Modeling of PBGC Insurance Protection}

Several presentations by Technical Panel members suggest that the PIMS model could be adapted to better integrate how risks affect both pension assets and liabilities jointly. Additionally most felt that these could be fruitfully co-managed using an Asset/Liability Management framework. In the past, PBGC assets have, during some periods, been invested 
independently from the Agency's liabilities, with investment policy changing back and forth over time between maximizing expected returns and a liability- driven approach. Some Panel members argue that it would be important to model particular industries and sectors posing most risk to the Agency, in which case the PIMS model could be used to align the Agency's investment policy with this broader attention to risks.

It is also worth emphasizing that, unlike a private-sector insurer, the PBGC's insurance premiums are set by Congress; that is, the PBGC has no statutory ability to set its own premiums or to deny coverage to extremely risky plans. As Babbel and several other Panel members note, this is problematic since the Agency faces large legacy costs and is unlikely to be able to close its funding gap with feasible premium increases. Additionally, the recently enacted legislation entitled Moving Ahead for Progress in the 21st Century Act (MAP-21) again deferred contribution hikes, thus exacerbating the problem. In the UK, by contrast, the Pension Protection Fund (PPF) has substantially more flexibility in setting premiums and specific objectives. Thus Clark reports that the PPF uses a stochastic approach to evaluate the risks and set risk-based premiums in a manner consistent with the Board's risk tolerance. As a consequence, the PPF's model is more cognizant of a variety of risks not currently embedded in the PBGC model, and the PPF prices for self-sufficiency in 2030.

A related issue is that the PIMS program does not incorporate potential moral hazard issues that could result from insured plans reacting to changes in PBGC or Congressional policy. The ME PIMS model does take into account the chance that mass withdrawals could result from a given plan, or that a plan could be rendered insolvent prior to a mass withdrawal. But the model does not permit the examination of how individual plan sponsors might respond, and a longer-term project would include the integration of such feedbacks. 


\section{Communication of Risk and Uncertainty}

The Technical Panel also devoted attention to how PBGC risk is communicated. This is important since key stakeholders, including Congress, plan participants, plan sponsors, and taxpayers, need to more clearly comprehend what might happen in bad states of the world which have become more salient than previously.

One way to explain pension system risk more intuitively is proposed by Maurer who points to the usefulness of a Conditional Value-at-Risk (CVaR), also known as the expected shortfall or "expected tail loss." This is widely used as a loss measure depicting the worst-case loss scenarios at a particular level of risk. This author recommends it as a possibly better risk measure that could be used when explaining the possible losses that might result from a PBGC shortfall.

Another issue under discussion is the time period over which system assets and liabilities are reported. Currently the PBGC reports mean values, along with the 'high' and 'low' 15 percentiles of the 5,000 SE simulations and $500 \mathrm{ME}$ simulations carried out, for 10 years into the future. Of course, as projections are made further into the future, the extent of uncertainty grows. Yet focusing on only a decade ahead implicitly downweights the liabilities that the Agency may have to pay in years thereafter. As a matter of fact, open plans today continue to accrue benefit promises that will need to be paid many more decades into the future.

It is worth noting that several other government entities that pay benefit promises long into the future, such as the Social Security Administration, are required to offer projections 75 years into the future, as well as “in perpetuity.” Additional sensitivity to longer payout periods in the PBGC context would offer additional perspective on future solvency considerations. ${ }^{9}$ Some

\footnotetext{
${ }^{9}$ Some argue that long-term projections may make more sense for a program like Social Security
} 
Panel members also favor highlighting the "date of exhaustion” of the PBGC's assets backing benefit promises, since this is a concept that is relatively easy to explain. Nevertheless, such information also has a history of being used to deflect attention from PBGC problems. For instance, some might ask why premiums should be raised today on plan sponsors, if the Agency has sufficient assets to pay more than 10 years of benefits.

The PBGC has also seen non-intuitive results in projections of the asset exhaustion date (at least in the SE program); for instance, the size of the deficit and the date of asset exhaustion often move in opposite directions. One reason is that large claims increasing the deficit may extend the date of asset exhaustion due to the inflow of plan assets when PBGC takes over a plan. And ultimately if Congress were to decide to bail out the PBGC in the event of insolvency, it is unclear which would be worse: a bailout that came sooner, or one that was later and probably more costly? In this case, one could reasonably question whether asset exhaustion dates belong on a short list of highlighted information points always provided by PBGC projections.

\section{Conclusions}

ERISA marks its $40^{\text {th }}$ anniversary in 2014. Despite the fact that this law was designed to ensure that participants in private sector defined benefit plans would have a secure retirement, concerns continue to mark debate over the future of US defined benefit plans. Few new DB plans are being created; many existing DB plans are frozen; some large plans continue to hover on the

which is projecting more predictable flows. The PBGC is subject to most of the same long-run uncertainties as Social Security, but this Agency has additional uncertainties that are more sensitive to difficult to predict events, including sponsor bankruptcies, voluntary components of funding decisions, voluntary decisions over sponsorship of PBGC insured plans, pension-related legislative changes (major changes have occurred in every recent decade), and market returns of different risky asset classes. Some panel members agreed with the limited value of longer-run projections of corporate bankruptcies, for instance. 
brink of termination; and the recent wave of de-risking suggests that fewer premiums will be flowing into the PBGC than anticipated. Moreover, many of the suggestions and recommendations outlined in the Technical Panel's comments would imply that a large transfer will be required, or insurance premiums raised substantially, and/or benefits curtailed, if the system is to be able to continue to provide some benefits to all of those who were promised retiree payouts.

The Technical Panel concurred that the PIMS models are an important and valuable tool in modeling the Agency's liability risk. To the best of our knowledge, there is no other model that can do a comparable job. Nevertheless, some improvements could be integrated in the Agency's approach. Among those deserving attention in the Technical Panel's view are the following:

- Incorporating systematic mortality risk;

- Including new asset classes increasingly found in defined benefit plan portfolios;

- Developing an updated model for the term structure of interest rates; and

- Incorporating an option value approach to pricing the insurance provided.

The Agency could also do more to communicate the range of uncertainty and potential for problems associated with the PBGC's financial status. This could include additional information including the Conditional Value-ay-Risk (CVaR), and perhaps an "intermediate,” “optimistic,” and a "pessimistic" set of projected outcomes, as well as the expected "date of exhaustion" for assets backing pension benefits insured by the PBGC. 


\section{References}

\section{Technical Panel Papers ${ }^{10}$}

Babbel, D. (2013). “Evaluating Pension Insurance Pricing,” Pension Research Council Working Paper WP2013-16. Philadelphia, PA: Pension Research Council.

Bone, C. (2013). “Actuarial Perspectives on Defined Benefit Pension Risk - Modeling Emerging Issues,” Pension Research Council (PRC) Working Paper WP2013-11. Philadelphia, PA: Pension Research Council.

Clarke, M. (2013). “Modeling Risk-based Pension Insurance Premiums in the UK,” Pension Research Council (PRC) Working Paper WP2013-13. Philadelphia, PA: Pension Research Council.

Fabozzi, F. (2013). “Measuring and Explaining Pension System Risk,” Pension Research Council Working Paper WP2013-14. Philadelphia, PA: Pension Research Council.

Fuerst, D. (2013). “Actuarial Assumptions \& Models for DB Pensions,” Pension Research Council Working Paper WP2013-10. Philadelphia, PA: Pension Research Council.

Geczy, C. (2013). “Financial Market Assumptions \& Models for Pension Plans: A Technical Comment on the PIMS Model Assumptions for Asset Markets,” Pension Research Council Working Paper WP2013-07. Philadelphia, PA: Pension Research Council.

Lucas, D. (2013). “Joint Risk of DB Pension Underfunding and Sponsor Termination: Incorporating Options-Based Projections and Valuations into PIMS,” Pension Research Council Working Paper WP2013-15. Philadelphia, PA: Pension Research Council.

Maurer, R. (2013). “Integrated Risk Management for Defined Benefit Pensions: Models and Metrics,” Pension Research Council Working Paper WP2013-09. Philadelphia, PA: Pension Research Council.

\footnotetext{
${ }^{10}$ These Technical Panel papers are available on the Pension Research Council website (www.pensionresearchcouncil.org).
} 
Novy-Marx, R. (2013). “Economic and Financial Approaches to Valuing Pension Liabilities,” Pension Research Council Working Paper WP2013-08 Philadelphia, PA: Pension Research Council.

Segal, D. (2013). “An Actuarial Perspective on Pension System Risk,” Pension Research Council Working Paper WP2013-12. Philadelphia, PA: Pension Research Council.

\section{Materials Supplied to the PIMS Technical Panel for Review}

Material Supplied by the SSA.

Lynchval Systems (2012). "Multiemployer PIMS - Known Limitations in ME-PIMS, Version 2.0” (Disclosures for Validation). Chantilly, VA: Lynchval Systems Worldwide, Inc., February 10.

Pension Benefit Guaranty Corporation (PBGC) (2009). “SE PIMS PPG App B,” Tech Architecture vFY09. Washington, DC: PBGC.

Pension Benefit Guaranty Corporation (PBGC) (2010). “A Brief Description of PIMS’ Source Code,” SE PIMS Programmers Guide. Washington, DC: PBGC.

Pension Benefit Guaranty Corporation (PBGC) (2010). “SE PIMS User Guide.” Washington, DC: PBGC.

Pension Benefit Guaranty Corporation (PBGC) (2010). “SE PIMS System Description.” Washington, DC: PBGC.

Pension Benefit Guaranty Corporation (PBGC) (2010). “ME PIMS System Description.” Washington, DC: PBGC, September 22.

Pension Benefit Guaranty Corporation (PBGC) (2010). “SE PIMS PPG App A,” Pension Insurance Modeling System (PIMS) Input Data Structure vFY09.1. Washington, DC: PBGC.

Pension Benefit Guaranty Corporation (PBGC) (2011). “PIMS Technical Specification - Update 
ME-PIMS Code to Accommodate ME Provisions of PRA 2010” (ME PIMS Pre-Rollout Specs 1 and 2, ME PIMS Post-Rollout Specs). Washington, DC: PBGC, February 6.

Pension Benefit Guaranty Corporation (PBGC) (2011). “Overview,” Multiemployer PIMS SystemValidation Documentation. Washington, DC: PBGC, February 7.

Pension Benefit Guaranty Corporation (PBGC) (2011). “Key Differences Between SE-PIMS and ME-PIMS,” Multiemployer PIMS System-Validation Documentation. Washington, DC: PBGC, February 7.

Pension Benefit Guaranty Corporation (PBGC) (2011). “SE PIMS Environment Plan FY11,” rev. March 25. Washington, DC: PBGC.

Pension Benefit Guaranty Corporation (PBGC) (2011) “Overview of the Pension Insurance Modeling System (PIMS).” Washington, DC: PBGC, April 27.

Pension Benefit Guaranty Corporation (PBGC) (2012). “A Brief History of PIMS.” Washington, DC: PBGC, September 27.

$\underline{\text { Other Material }}$

Buck Consultants (2012). “ME-PIMS Peer Review Report,” Letter from Buck Consultants to Larry Shirley of the Pension Benefit Guaranty Corporation. Berwyn, PA: Buck Consultants, September 12.

Congressional Budget Office (CBO) (2005). “The Risk Exposure of the Pension Benefit Guaranty Corporation.” Washington, DC: CBO, September.

U.S. Government Accountability Office (GAO) (1997). 1997 PBGC Report. Washington, DC: GAO.

Pension Benefit Guaranty Corporation (PBGC) (2012). “Excellence in Customer Service,” FY2012 Annual Report. Washington, DC: PBGC.

Pension Benefit Guaranty Corporation (PBGC) (2012). “Press Release: FY 2012 PBGC Exposure Report.” Washington, DC: PBGC. 
Society of Actuaries (SOA) (2012). "Proposed Pension Funding Stabilization: How Does It Affect the Single-Employer Defined Benefit System?” SOA Research Report. Schaumburg, IL: SOA. 


\section{Appendix: Meeting Agenda}

\section{Technical Review Panel for the PIMS Model}

Hosted by the Pension Research Council, \& Michigan Retirement Research Center

April 24, 2013, The Wharton School

Moderator and Organizer:

Olivia S. Mitchell, The Wharton School of the University of Pennsylvania

\section{Understanding Defined Benefit Plan Asset and Liability Risk}

Chris Geczy, The Wharton School: "Financial Market Assumptions \& Models for Pension Plans:

A Technical Comment on the PIMS Model Assumptions for Asset Markets”

Robert Novy-Marx, University of Rochester: "Economic and Financial Approaches to Pension Liabilities"

Raimond Maurer, Goethe University, Frankfurt: "Integrated Risk Management for Defined Benefit Pensions: Models and Metrics”

\section{Actuarial Perspectives on Defined Benefit Pension Plan Risk}

Don Fuerst, American Academy of Actuaries: “Actuarial Assumptions \& Models for DB Pensions”

Chris Bone, Edth Ltd.: “Actuarial Perspectives on Defined Benefit Pension Risk - Modeling Emerging Issues”

Don Segal, former President, Society of Actuaries: “An Actuarial Perspective on Pension System Risk”

\section{Keynote}

Martin Clarke, Pension Protection Fund (UK): "Modeling Risk-based Pension Insurance Premiums in the UK"

\section{III.Understanding Pension System Risk}

Frank Fabozzi, EDHEC: "Measuring and Explaining Pension System Risk"

Debbie Lucas, MIT: Joint Risk of DB Pension Underfunding and Sponsor Termination: Incorporating Options-Based Projections and Valuations into PIMS.

\section{IV.Pension Insurance: Risk Pricing Perspectives}

David Babbel, Wharton (Emeritus): "Evaluating Pension Insurance Pricing” 